\title{
Article \\ Project Governance and Project Performance: The Moderating Role of Top Management Support
}

\author{
Muhammad Zeeshan Fareed ${ }^{1, *(\mathbb{D})}$ and Qin $\mathrm{Su}^{1,2,3}$ \\ 1 School of Management, Xi'an Jiaotong University, Xi'an 710049, China; qinsu@mail.xjtu.edu.cn \\ 2 State Key Laboratory for Manufacturing Systems Engineering, Xi'an 710049, China \\ 3 The Key Laboratory of the Ministry of Education for Process Control \& Efficiency Engineering, \\ Xi'an 710049, China \\ * Correspondence: fareed@stu.xjtu.edu.cn
}

check for updates

Citation: Fareed, M.Z.; Su, Q. Project Governance and Project Performance: The Moderating Role of Top Management Support. Sustainability 2022, 14, 2516. https://doi.org/ $10.3390 /$ su14052516

Academic Editors: Willie Tan and Robert Lee Kong Tiong

Received: 19 January 2022

Accepted: 18 February 2022

Published: 22 February 2022

Publisher's Note: MDPI stays neutral with regard to jurisdictional claims in published maps and institutional affiliations.

Copyright: (c) 2022 by the authors. Licensee MDPI, Basel, Switzerland. This article is an open access article distributed under the terms and conditions of the Creative Commons Attribution (CC BY) license (https:// creativecommons.org/licenses/by/ $4.0 /)$.

\begin{abstract}
Project governance (PG) has been primarily acknowledged as critical by researchers and practitioners in regard to successfully executing projects. However, project governance of public projects has received less attention from researchers. Therefore, in this study, we studied the effects of project governance and top management support (TMS) on project performance (PP) and their interactions in public sector projects. Using the lens of resource dependence theory (RDT), we hypothesize whether TMS moderates the impact of PG on PP. A quantitative deductive approach was employed to examine this relationship. Quantitative data were collected using a structured questionnaire from 346 project managers, team members, and stakeholders. Our results indicated that PG and TMS are positively significantly correlated with project performance. Moreover, we found that TMS acts as a quasi-moderator in the relationship between PG and PP.
\end{abstract}

Keywords: project performance; project governance; top management support; megaprojects; Belt and Road Initiative (BRI); Pakistan

\section{Introduction}

Industry growth and globalization have boosted projects in various fields, including IT, construction, the social sector, and security [1]. Worldwide economic statistics show a substantial and growing practice of project management (PM) systems around the world $[2,3]$. Corporations that apply PM techniques are required to be more adept at responding to risks or opportunities [3]. Around the world, the investment budget for projects has increased dramatically, which now amounts to billions [4]. These growing numbers indicate the growing need for better, quicker, and more profitable projects, and with this escalating requirement, project execution is getting tougher for project managers [3]. It was noted, that public sector projects did not produce the expected results, even after taking into account recognized project management principles [5,6].

Administrations in low and high-revenue countries invest significant capital in public projects each year [7]. However, the public sector project performance (PP) rate stays low $[7,8]$. "Public sector project management inefficiency is a serious problem for many countries" [2]. This inefficiency is due to ineffective PG, which is also one of the causes of the poor performance of public projects [9-11]. Researchers have also noted that inefficient public project performance is the consequence of structural complexity [12,13].

Public sector project management ought to enhance "the ability to achieve outcomes" [14]. In the face of futile project performance comprising significant delays, cost overruns, and inadequate economic benefits, governments have started implementing governance frameworks to enhance project performance [15]. Much research has been done on these governance frameworks and their influence on PP [16-18].

Pakistan's governmental divisions are also working at various levels to increase the development of project performances through different mechanisms $[19,20]$. Nevertheless, 
significant developments are needed to attain the anticipated performance indicators $[19,20]$. Pakistan is a strategic partner in China's "Belt and Road Initiative (BRI)," which has accelerated the flow of direct foreign investment in infrastructure projects in Pakistan [21]. These mega-projects are major economic growth and prosperity factors in the country [22]. One of the causes for unsatisfactory public project performance in Pakistan is project governance (PG) [23]. Pakistan's government policies and planning departments face challenges due to complex public sector processes, lack of skills, resources provision, and an inefficient bureaucratic system [21].

Governance defines the objectives of the project, the ways in which the necessary resources are obtained, and the way in which progress is monitored [24-26]. McGrath and Whitty [27] characterized PG as the system or the organizational governance (OG) of a project by which an organization directs, controls, and takes responsibility for a project. Previous studies on PG have concentrated mainly on fixed organizational procedures and arrangements and left the scope of research on micro-level practices that occur at the project level throughout the project lifecycle [24,28,29].

In the resource dependence theory (RDT), the ultimate success of an organization depends mainly on the organization's skill to manage its internal and external resources [30]. In an appropriate project governance mechanism, the project board and the project owner play essential roles in tackling the problem and by giving core resources [31]. Top management support (TMS) strengthens project manager leadership by fulfilling resources needs [32], communications aid, and empowerment, ultimately contributing to PP [33]. TMS also helps project managers in team motivation, resource allocation, and prioritization of tasks, and TMS helps in smoothing the hurdles in innovation projects [34]. Furthermore, senior management plays a critical role in delivering and generating the conditions for PP [35], two of which can be denoted as 'technology-use-mediation' or 'meta-structuring' [36]. Therefore, this study has the following research questions:

1. How is PG associated with public project performance in Pakistan?

2. Does TMS moderate the relationship between PG and PP of public sector projects in Pakistan?

Several researchers and academicians have used the term project governance with various implications and meanings [24,37,38]. In this study, we explore public projects governance, how top management affects project governance and performance, and how governance is conducted in the public sector at the project level. The remainder of the paper is arranged in the following method: the literature review addresses PP, TMS, and PG. The methodology is then delineated, followed by the analysis. The final sections are devoted toward the discussion and conclusions.

\section{Literature Review}

This study integrates a post-positivist approach within the resource dependence theory framework, presented by Pfeffer and Salancik [39].

\subsection{Project Performance}

Academics and project management practitioners gradually recognize that the wellknown "iron triangle" criteria for success of time, cost, and quality are imperfect $[40,41]$. Furthermore, Shenhar and Dvir [42] stated that the idea of PP could be more complicated than the two consequences of success and failure. Examples, such as the Hubble Telescope and the Sydney Opera House, reveal that a project may fail in terms of yield efficacy; still, it can be considered a success in investment efficiency [42]. Achieving desired results within quality, budget, and schedule constraints in a project does not always mean a successful investment if it fails to bring the expected outcomes [41].

The concept of "success" and "failure" of a project is debatable in some situations. For instance, canceling a project owing to changing business situations does not essentially mean failure. Due to these reasons, current project success rate estimations may not accurately depict [43]. Performance evaluation in public management has changed from 
simple management of inputs and outputs to multiple goals [2], such as "service outputs, satisfaction, outcomes, maintaining trust and legitimacy" [44]. Albert, Balve [45] examined $\mathrm{PP}$ in various areas in the literature, and the authors defined that the success criteria were time, performance, and cost, including economic success and quality. Davis [46] created a set of three new dimensions of PP that include stakeholders' benefits, the customer or specific client concerns, and the standard dimensions of cost, time, and quality.

Several researchers have attempted to better understand the critical success criteria used by different groups [47]; however, this research only covered the public sector to a minimal extent [48]. Likewise, methods for assessing private investment performance have not be applied in the public sector, as public projects produce social benefits that are not traded on the market [2]. Critical aspects of public projects, sustainability, or political influence are generally ignored when public success criteria are mentioned [49]. Whenever the term PP is referred to in this study, it encompasses both the project management success and project success as defined by Cooke-Davies [50].

\section{2. $P G$ and $P P$}

PG, described by Project Management Institute $\left(\mathrm{PMI}^{\circledR}\right)$, is "an oversight function that is aligned with the organization's governance model and that encompasses the project lifecycle [and provides] a consistent method of controlling the project and ensuring its success by defining and documenting and communicating reliable, repeatable project practices" [51]. Brunet and Aubry [15] advocated that PG supports administrative and managerial activities in public projects and improves stakeholder management. Project governance provides a structured approach to managing project progress, allowing relevant stakeholders to understand and affect the decision-making process throughout the project life cycle [52].

PG is a new paradigm of governance that improves the chances of PP [53]. PG forms a framework of accountability and benefits management that ensures the project realizes the business case [43]. PG offers a formal framework for identifying and resolving risks as they appear during project implementation [54]. PG affects PP directly and moderates the relationship between OG and PP [55].

PG increases project performance by expediting timely and efficient control and risk allocation [56]. PG is a compelling component to benefit and support the requirement for superior management of public sector projects [53]. In contrast, the ineffective governance mechanism has proven to be one of the leading reasons for disasters in many projects $[10,57,58]$. $\mathrm{Lu}$, Liang [59] studied the relational and the contractual modules of governance and established their positive relationship with the success of the public project. Hence, we have our first hypothesis.

\section{Hypothesis 1 (H1). PG positively influences PP.}

\subsection{TMS and PP}

Top management plays a vital role in creating an environment [32] where project managers understand and manage team members' emotions, motivate them, encourage them, and put forth their utmost efforts to achieve personal and project goals $[60,61]$. Young and Poon [62] concluded that top management-backed projects are unlikely to fail. Ali, $\mathrm{Li}$ [60] claimed that the senior management's leadership role, interests, comprehensions, and incentives are essential features for a project's success. A critical aspect of management support is making resources available on time [63]. Several authors have agreed on the need for the TMS as an independent variable for the PP [64,65].

Top management has a critical part in facilitating and supplying the resources necessary for project success [35]. Various researchers have established the significance of TMS for the best success of the information systems project $[61,66]$; the recommendation in the literature is to secure TMS for the project to ensure a secure path to success [32]. The 
literature specifies that there may be differences in the type, level, or nature of support from top management during a project [67].

To implement organizational strategies, projects are used, and TMS is thought to be a crucial element in PP, but the deficiency of TMS can be found in most of the projects [68]. Sometimes high-level planning or assistance is sufficient for the project's success, but TMS is nearly always vital for the project's success [62]. Project results depend on TMS, and it has been repeatedly found that TMS contributes significantly to the project's success [69-71]. Therefore, our second hypothesis is

Hypothesis 2 (H2). TMS positively influences PP.

\subsection{The Moderating Role of TMS}

RDT proposes that organizational success hinges on the organization's capability to manage interdependent internal and external resources $[30,39,72]$ and provides valued understandings of prioritization and allocation, and facilitation of organizational resources [73]. A company's resource base provides critical points of contact when organizations participate in transactions and exchanges and, consequently, plays an imperative role in accomplishing organizational success [39]. The diversity of available resources can be exclusive to an organization and thus can influence its OG structure [74].

In an appropriate project governance mechanism, the project board and the project owner play a major role in resolving the issues by supplying TMS, including core resources [31]. TMS strengthens project managers' leadership by fulfilling resources needs, communications aid, and empowerment, ultimately contributing to project success [33]. TMS helps the project manager in team motivation, resource allocation, and prioritization of tasks; TMS also helps smooth the hurdles in innovation projects [34]. Senior management impacts projects in various ways, appointing project managers, building a culture of cooperation, strategic planning, assigning project resources, and executing project processes [61]. Top management also has an essential job of furnishing the desired resources and supporting the project manager for its success [75]. After this discussion, we hypothesize

Hypothesis 3 (H3). TMS moderates the relationship between PG and PP, such that TMS strengthens the relationship between $P G$ and $P P$.

The preceding discussion leads us to the explanatory paradigm and the hypotheses proposed in the conceptual model (Figure 1). PG and TMS are proposed to have an impact on PP. Moreover, TMS moderates the relationship between PG and PP.

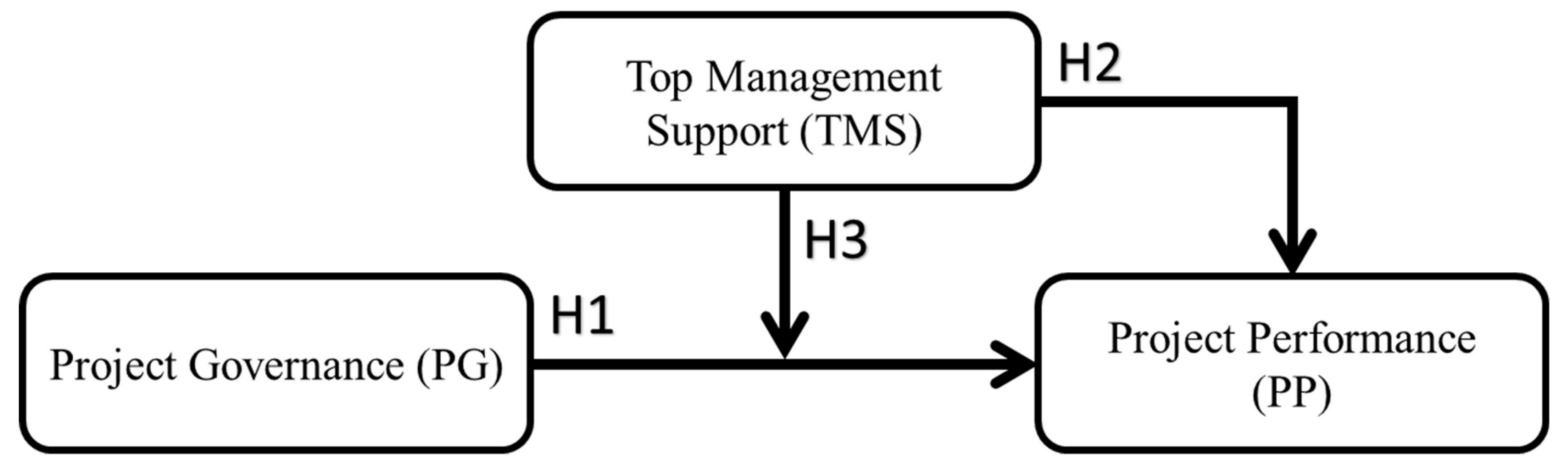

Figure 1. Conceptual model.

\section{Research Methodology}

To observe the theoretical model, this research uses a post-positivism philosophical lens. Post-positivism "assumes that the world is mainly driven by generalizable (natural) laws, but their application and results are often situational dependent. Postpositivist researchers therefore identify trends; that is, theories which hold in certain situations, but 
cannot be generalized" [76]. The post-positivist approach suits well with social science research, and it has appeared as the central philosophy of quantitative research in the social sciences [77]. To collect quantitative data, we used a cross-sectional survey design.

\subsection{Sample and Procedure}

A time-lagged methodology was used to collect data from multiple sources (team members, project managers, stakeholders) for this study to shun common source bias (CSB) [78]. Pakistan Manpower Institute, Islamabad, imparts training to Pakistan's public officers employed on public projects. Contact details were obtained from Pakistan Manpower Institute. At T1, we sent emails and letters with 600 printed questionnaires to project teams working on various projects all around the country. We requested them to provide our survey data from project managers, team members, and stakeholders. We guaranteed anonymity and confidentiality. Respondents were requested to rate TMS and PG. We received 481 completed questionnaires. The same 481 respondents were contacted to rate PP at T2. A total of 346 completed questionnaires were returned, with an overall response rate of $69.2 \%$, which is adequate according to Pesämaa, Zwikael [79].

Data were collected in about three months. Harmon's single factor (HSF) was applied to calculate the common method bias (CMB). According to recent studies [79], it is a pretty effective method. A single factor appears from the factor analysis in the HSF test and, if this single factor shows more than $50 \%$ of the variance, this may confirm that there may be a CMB [80]. Our results confirmed that CMB is not a concern for our study. Furthermore, "One form of endogeneity is omitted variable bias. By including relevant (and only relevant) control variables, we come much closer to the truth" [79]. Therefore, we have used gender, age, education, and experience as control variables. These variables are associated with PP, and researchers have suggested these as control variables [81]. We also used $t$-test to check the responses from different groups as recommended by Müller, Turner [82]. The demographics are displayed in Table 1.

Table 1. Demographic data.

\begin{tabular}{|c|c|c|c|}
\hline Characteristics & Category & Frequency & Cumulative Percent \\
\hline \multirow{2}{*}{ Gender } & Male & 278 & 80.3 \\
\hline & Female & 68 & 100.0 \\
\hline \multirow{4}{*}{ Education } & Less than 16 years & 8 & 2.0 \\
\hline & 16 years $(\mathrm{BS})$ & 234 & 69.7 \\
\hline & 18 years (MS) & 78 & 92.2 \\
\hline & Above 18 years $(\mathrm{PhD})$ & 27 & 100.0 \\
\hline \multirow{8}{*}{ Age Group } & $25-30$ & 102 & 29.5 \\
\hline & $31-35$ & 52 & 44.5 \\
\hline & $36-40$ & 45 & 57.5 \\
\hline & $41-45$ & 77 & 79.8 \\
\hline & $46-50$ & 25 & 87.0 \\
\hline & $51-55$ & 34 & 96.8 \\
\hline & $56-60$ & 2 & 97.4 \\
\hline & 61 and above & 9 & 100.0 \\
\hline \multirow{7}{*}{ Experience } & $1-5$ & 148 & 42.8 \\
\hline & $6-10$ & 20 & 48.6 \\
\hline & $11-15$ & 20 & 54.3 \\
\hline & $16-20$ & 42 & 66.5 \\
\hline & $21-25$ & 89 & 92.2 \\
\hline & $26-30$ & 23 & 98.8 \\
\hline & 31 and above & 4 & 100.0 \\
\hline
\end{tabular}

\subsection{Measures}

This study involved one independent variable, one moderator, and one dependent variable (conceptual model is displayed in Figure 1). The independent variable is PG, TMS 
is the moderator, and the dependent variable is PP. We adopted previous studies measures for all variables. Respondents rated the variables on a 5-point Likert scale ( 1 = strongly disagree to 5 = strongly agree).

The measurement instruments for each of the variables are described below.

\subsubsection{Independent Variables}

We used Haq, Liang [83] scales to measure PG. This scale has eight items. Scott-Young and Samson [84] scales were used to measure TMS. This scale consists of five items.

\subsubsection{Dependent Variables}

Aga, Noorderhaven [81] scales were applied to assess PP. The scale constructs are time, budget, client use, satisfaction, effectiveness, and performance. This scale has 13 items. These scales are validated, reliable, and consistent with previous studies [69,85-87].

\subsection{Reliability and Validity}

Internal consistency is usually used to check the scale reliability. Churchill [88] endorsed the Cronbach's alpha $(\alpha)$ usage for verifying the scale's quality. Anderson and Gerbing [89] suggested that the Cronbach's alpha $(\alpha)$ values should be 0.7 or above. For our study, values of Cronbach's alpha $(\alpha)$ for all constructs are greater than 0.7 . To verify the constructs' validity, we first used exploratory factor analysis. Data analysis results confirmed that all of the constructs showed eigenvalues greater than 1 , and the factor loadings were higher than 0.5 for all the respective constructs. Furthermore, as indorsed by Hair, Black [90], Bartlett's test of sphericity must be significant $(p<0.001)$, KMO's value must be greater than 0.60 , and correlation among variables must be higher than 0.30 (as displayed in Table 2).

Table 2. KMO.

\begin{tabular}{cccccc}
\hline Variable & KMO & Bartlett's Test of Sphericity & DF & $\boldsymbol{p}$-Value & Cronbach's $\boldsymbol{\alpha}$ \\
\hline PG & 0.81 & 1057.13 & 36 & 0.000 & 0.83 \\
TMS & 0.87 & 414.72 & 10 & 0.000 & 0.80 \\
PP & 0.75 & 1537.82 & 78 & 0.000 & 0.82 \\
\hline
\end{tabular}

To validate the analytical data, the Anderson and Gerbing [89] CFA model was applied. Indices of model fitness were adequate as advised by Hair, Black [90], RMSEA values should be in the range (0.03-0.08), and CFI and TLI values should be greater than 0.90 . Our results exhibit a good fit to the data (as demonstrated in Table 3).

Table 3. Model Fit.

\begin{tabular}{ccccc}
\hline CMIN/Df & TLI & GFI & CFI & RMSEA \\
\hline 1.99 & 0.95 & 0.95 & 0.96 & 0.04 \\
\hline
\end{tabular}

We also used composite reliability (CR) and average variance extracted (AVE) values to check the discriminatory and convergent validities [91]. The AVE values should be greater than or equal to 0.50 for convergent validity. Simultaneously, CR values should be greater than 0.60 [92]. The square root of the AVE of a construct should exceed the correlation of that construct with other constructs in the model for discriminant validity. Our results proved the convergent and discriminator validities.

\section{Data Analysis and Results}

AMOS-21 and SPSS-21 software were used for statistical assessment. We have examined hypotheses using correlation and hierarchical regression analysis (HRA). Data were meticulously checked for missing data, normality, outliers, and multi-collinearity before 
the statistical assessment. We checked multi-collinearity by variance inflation factor (VIF). All values of VIF for our study were below 3. Likewise, kurtosis and skewness were in the acceptable range.

\subsection{Descriptive Statistics and Correlation}

All constructs presented stable constancy. The project performance, top management support, and project governance verified a significant correlation among the variables. After analytical calculations, our results (Table 4 ) were in the acceptable range and were significant statistically $(p<0.05)$.

Table 4. Descriptive statistics.

\begin{tabular}{cccccccccc}
\hline Variable & Mean & SD & $\mathbf{1}$ & $\mathbf{2}$ & $\mathbf{3}$ & $\mathbf{4}$ & $\mathbf{5}$ & $\mathbf{6}$ & $\mathbf{7}$ \\
\hline Gender & 1.19 & 0.39 & 1 & & & & & & \\
Age & 3.07 & 1.86 & $0.14^{* *}$ & 1 & & & & & \\
Education & 2.36 & 0.65 & -0.01 & 0.042 & 1 & & & & \\
Experience & 2.96 & 1.92 & 0.06 & -0.02 & 0.011 & 1 & & & \\
PG & 3.20 & 0.78 & 0.08 & 0.01 & 0.035 & 0.02 & 1 & & \\
TMS & 3.49 & 0.90 & 0.01 & 0.08 & 0.055 & 0.04 & $0.37^{* *}$ & 1 & \\
PP & 3.61 & 0.69 & $0.11^{*}$ & 0.02 & 0.007 & 0.06 & $0.50^{* *}$ & $0.47^{* *}$ & 1 \\
\hline
\end{tabular}

** Correlation is significant at the 0.01 level. * Correlation is significant at the 0.05 level.

\subsection{Moderation Analysis}

Moderation analysis is used to determine whether the affiliation between PG and PP depends on the TMS. We employed a process developed by Sharma, Richard [93] to know the type of moderator. There are two types of moderator variables in literature: pure and quasi-moderators [94]. The moderation analysis is essentially a multiple regression equation with interactive elements. Hierarchical regression analysis is used to test perceived interaction as proposed by Sharma, Richard [93]. Table 5 displays the results of moderation analysis. The results (Table 5) showed that TMS is significant in model 1 and model 2. The interaction term in model 3 is also significant. This indicates that TMS acts as a quasi-moderator in the relationship between PG and PP.

Table 5. Moderation Analysis.

\begin{tabular}{ccccccc}
\hline Model & Variable & Beta & T Values & Sig. & $\mathbf{R}^{\mathbf{2}}$ & F Value \\
\hline \multirow{4}{*}{1} & Age & 0.02 & 0.69 & 0.488 & & \\
& Gender & 0.05 & 1.32 & 0.185 & & \\
& Education & -0.01 & -0.46 & 0.641 & 0.50 & 68.54 \\
& Experience & 0.04 & 1.18 & 0.237 & & \\
& PG & 0.69 & 18.17 & 0.000 & & \\
2 & Age & -0.00 & -0.11 & 0.908 & & \\
& Gender & 0.06 & 1.76 & 0.078 & & \\
& Education & -0.03 & -0.90 & 0.369 & 0.61 & \\
& Experience & 0.03 & 0.93 & 0.350 & & \\
& PG & 0.46 & 11.25 & 0.000 & & \\
& TMS & 0.40 & 9.70 & 0.000 & & \\
& Age & -0.00 & -0.11 & 0.907 & & \\
& Gender & 0.06 & 1.74 & 0.081 & & \\
& Education & -0.03 & -0.94 & 0.346 & & \\
& Experience & 0.02 & 0.78 & 0.435 & 0.71 & \\
& PG & 0.32 & 2.27 & 0.000 & & \\
& TMS & 0.26 & 2.10 & 0.000 & & \\
& (PG $\times$ TMS) & 0.26 & 2.09 & 0.000 & & \\
\hline
\end{tabular}




\section{Discussion}

\subsection{Hypothesis Testing}

H1: "PG positively influences PP" is accepted. The beta value $(\beta=0.475)$ confirms the relationship between PG and PP, which is aligned with previous studies $[21,83,95,96]$.

H2: "TMS positively influences $P P^{\prime}$ " is also accepted. The value of $\beta=0.401$ validates our hypothesis. The research findings are aligned with the previous studies $[62,66,67,97]$.

H3: "TMS moderates the relationship between PG and PP, such that TMS strengthens the relationship between PG and PP" is accepted. The values in Table 5 confirm that TMS acts as a quasi-moderator. The interaction effect is exhibited in Figure 2.

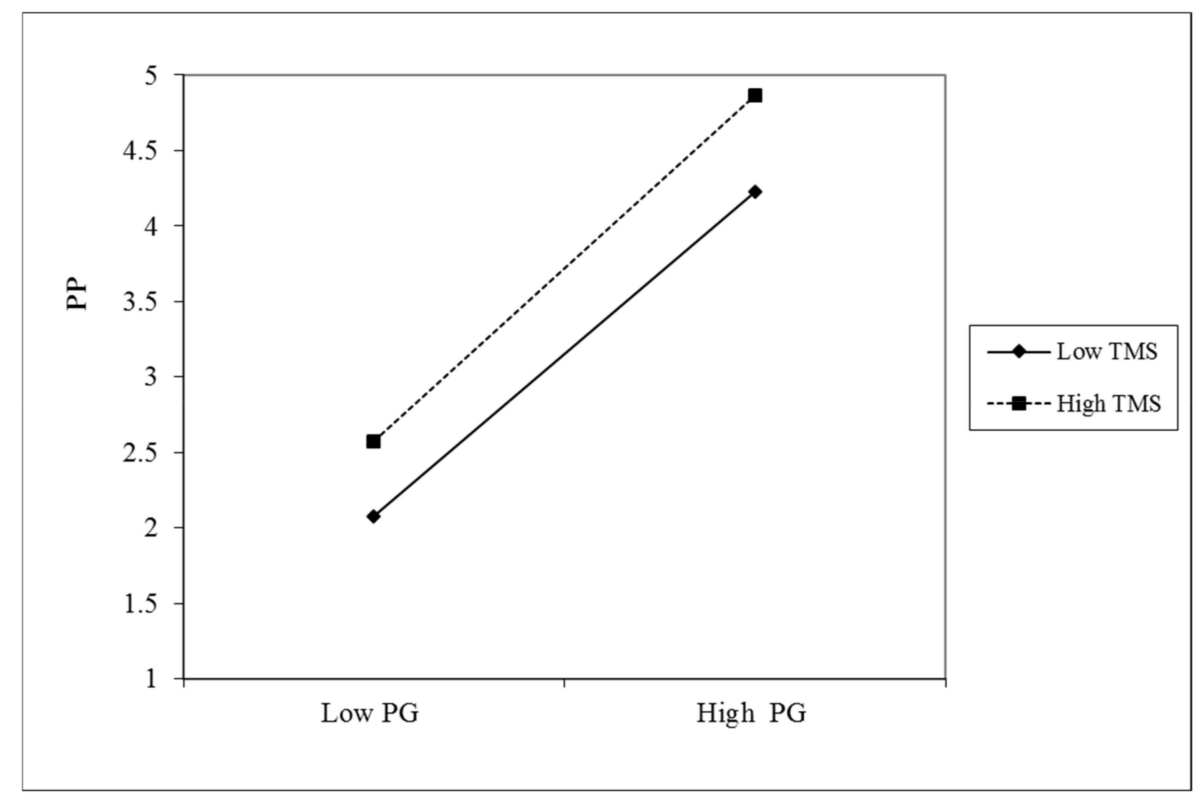

Figure 2. Moderation Analysis.

\subsection{Theoretical Implications}

The research aims to observe the effect of PG on PP with the TMS moderating effect. The results show that TMS strengthens the relationship between PG and PP (as illustrated in Figure 2). This study has numerous significant contributions to the current body of knowledge about PG and PP. First, the public projects in developing countries struggle due to limited resources, governance, political influences, and bureaucratic systems. However, very few studies in the literature have engrossed the public sector projects of a developing country, such as Pakistan. As per the authors' knowledge, this is the first study providing insights into PG and the performance of public projects in the context of TMS. Prior research has investigated the relationship between PG and PP; however, this has not been specific enough to guide practitioners in top management. Moreover, this study was imperative as recent studies have indicated that top management is often loath to take an active role during the project life cycle because they view projects as operational concerns rather than strategic tools [98].

Furthermore, this study delivered context and culture-specific findings of Pakistan's public sector and addressed the aforementioned contextual and theoretical gap. Secondly, this study's results will support extending the literature to developing countries by furnishing groundbreaking empirical evidence from Pakistan. As noted earlier, most of the research is conducted in the Western context [99]. Thirdly, we found that PG and TMS interact with each other to engender project performance. Hence, given appropriate TMS, the PG will enhance the chances of PP. These results reveal that although governance of public projects is important, the driver for sustained superior performance is a combination of the PG in the organization and supportive top management. Finally, these findings will contribute to the governance school of PM. 


\subsection{Practical Implications}

The resource dependency theory considers resources as the main drivers of an organization's governance structure. Therefore, this theory of governance can assist in understanding the significance of prioritizing and allocating the various resources that are frequently shared between programs and project portfolios. Moreover, TMS has crucial importance in the public sector. In light of the empirical evidence, the study proposes that the percentage of successful projects can be increased by providing resources on time, making structural changes to facilitate systemic changes, communicating with team members to stimulate and selling projects to all project stakeholders, and sharing knowledge and experience, using the formal system. Different PG and TMS constructs suggest that employees can avoid perceived risks associated with projects and complete the project successfully with authority to resolve project disputes, introduce innovative working methods, while adhering to institutional standards as suggested in earlier studies [100].

Moreover, our study also proposes that top management must deliver training to the project team before the project starts. The team should be aware of the stakeholder management and the final product they require from the employees as indorsed in earlier research [21]. Our findings suggest management must effectively define the project for project teams. Furthermore, this research has the following managerial implications, based on our study findings:

a. PG should confer substantial consideration to improving the performance of public projects. Generally, the public sector has well-structured governance frameworks [101], assisted by control mechanisms, appropriate approaches, and resources applied during all project phases. However, in light of empirical evidence, the study recommends that top management improve the resource management system and ensure resource availability before and during the project execution as governments contest to fulfil public requirements within limited budgets.

b. Our findings, aligned with previous research, also suggest that top management should give considerable attention to the project environment, as it is crucial for team performance [35], and should regularly communicate with the project team and other stakeholders [21].

c. In consultation with project managers for risk management, the top manager (or project sponsor) should estimate the resources necessary for comprehensive project planning during project execution, and judiciously define project milestones.

d. Public project managers should have the capability to be given resources and authority by top management to make the right decisions. Top management can also positively influence projects by hiring competent project managers [61].

e. Lastly, top management or its delegated agents should continuously appraise ongoing projects. Public project evaluations should focus on sustainability's triple bottom line concept, which includes economics, environmental, and social impacts [102]. Our findings also endorse earlier research that accountability can be improved by assigning a project sponsor to every project [103].

\section{Limitations and Future Research}

We recognize some limitations to our study. First, this research was conducted in one country and the public sector setting. Although respondents were from different departments and working on different types of projects. Our findings may have inadequate generalizability. These results may differ in different settings. However, the same model can be used to observe the relationship between PG and PP in different settings, such as non-profit organizations or the private sector. Second, we used a time-lagged methodology and collected data from multiple sources. We also used relevant control variables. However, reverse causality and omitted variables are significant concerns in cross-sectional research design [104]. Lastly, another study limitation is also caused by quantitative research design, limiting its capability to dictum the complex relationships between the concepts under study. Future research can use qualitative designs to further investigate how TMS affects 
the relationship between PG and PP and how these two concepts affect the performance of projects.

\section{Conclusions}

The research's primary objectives were to observe the effects of PG on PP with the TMS moderating effect. The current study took a post-positivist perspective to analyze the relationships among PG, TMS, and PP. Our results have revealed positive relationships among PG, TMS, and PP, with TMS as a quasi-moderator, which has never been investigated before. Our findings align with prior research suggesting that public sector organizations should understand the significance of PG, as it offers decision-making models, project management tools, and a framework for organizational processes, which benefit the successful implementation of portfolios, programs, and projects [100]. Our findings also suggest that PG increases project and organizational performance by risk mitigation and management and improves transparency by regular reporting and clearly defining roles and responsibilities of project managers and sponsors, which are imperative features of public projects. Moreover, TMS can strengthen the PG and PP relationship by effectively providing and managing resources, creating a work environment, sharing organizational objectives, delegating authority, and communicating with stakeholders. The study's contribution to knowledge is in its investigation of top management's role in the governance of projects. It has taken us a step forward in developing project governance and performance knowledge.

Author Contributions: Conceptualization, M.Z.F.; investigation, M.Z.F.; formal analysis, M.Z.F.; methodology, M.Z.F.; data curation, M.Z.F.; writing—original draft preparation, M.Z.F.; validation, M.Z.F. and Q.S.; writing—review and editing, M.Z.F. and Q.S.; supervision, Q.S.; funding acquisition, Q.S. All authors have read and agreed to the published version of the manuscript.

Funding: This research received no external funding.

Institutional Review Board Statement: Not applicable.

Informed Consent Statement: Informed consent was obtained from all subjects involved in the study.

Data Availability Statement: The data presented in this study are available on request from the corresponding author.

Acknowledgments: The authors are grateful to the Pakistan Manpower Institute, editors, and anonymous reviewers for their constructive and thoughtful suggestions.

Conflicts of Interest: The authors declare no conflict of interest.

\section{References}

1. Yatim, F.; Bredillet, C.N.; Ruiz, P. Investigating the deployment of project management: A new perspective based on the concept of certification. Int. J. Manag. Proj. Bus. 2009, 2, 445-454. [CrossRef]

2. Kossova, T.; Sheluntcova, M. Evaluating performance of public sector projects in Russia: The choice of a social discount rate. Int. J. Proj. Manag. 2016, 34, 403-411. [CrossRef]

3. Anantatmula, V.S. The Role of Technology in the Project Manager Performance Model. Proj. Manag. J. 2008, 39, 34-48. [CrossRef]

4. Williams, T. Assessing and Moving on From the Dominant Project Management Discourse in the Light of Project Overruns. IEEE Trans. Eng. Manag. 2005, 52, 497-508. [CrossRef]

5. Patanakul, P.; Kwak, Y.H.; Zwikael, O.; Liu, M. What impacts the performance of large-scale government projects? Int. J. Proj. Manag. 2016, 34, 452-466. [CrossRef]

6. Nidiffer, K.; Dolan, D. Evolving Distributed Project Management. IEEE Softw. 2005, 22, 63-72. [CrossRef]

7. Flyvbjerg, B. What you Should Know about Megaprojects and Why: An Overview. Proj. Manag. J. 2014, 45, 6-19. [CrossRef]

8. Sirisomboonsuk, P.; Gu, V.C.; Cao, R.Q.; Burns, J.R. Relationships between project governance and information technology governance and their impact on project performance. Int. J. Proj. Manag. 2018, 36, 287-300. [CrossRef]

9. Han, S.H.; Yun, S.; Kim, H.; Kwak, Y.H.; Park, H.K.; Lee, S.H. Analyzing schedule delay of megaproject: Lessons learned from Korea Train eXpress (KTX). IEEE Trans. Eng. Manag. 2009, 56, 243-256. [CrossRef]

10. Patanakul, P. Managing large-scale IS/IT projects in the public sector: Problems and causes leading to poor performance. J. High Technol. Manag. Res. 2014, 25, 21-35. [CrossRef] 
11. Kwak, Y.H.; Smith, B.M. Managing risks in mega defense acquisition projects: Performance, policy, and opportunities. Int. J. Proj. Manag. 2009, 27, 812-820. [CrossRef]

12. Kwak, Y.H.; Walewski, J.; Sleeper, D.; Sadatsafavi, H. What can we learn from the Hoover Dam project that influenced modern project management? Int. J. Proj. Manag. 2014, 32, 256-264. [CrossRef]

13. Williams, T. Identifying the hard lessons from projects-Easily. Int. J. Proj. Manag. 2004, 22, 273-279. [CrossRef]

14. Crawford, L.H.; Helm, J. Government and Governance: The Value of Project Management in the Public Sector. Proj. Manag. J. 2009, 40, 73-87. [CrossRef]

15. Brunet, M.; Aubry, M. The three dimensions of a governance framework for major public projects. Int. J. Proj. Manag. 2016, 34, 1596-1607. [CrossRef]

16. Klakegg, O.J.; Williams, T.; Shiferaw, A.T. Taming the 'trolls': Major public projects in the making. Int. J. Proj. Manag. 2016, 34, 282-296. [CrossRef]

17. Christensen, T. The Norwegian front-end governance regime of major public projects. Int. J. Manag. Proj. Bus. 2011, 4, 218-239. [CrossRef]

18. Williams, T.; Klakegg, O.J.; Magnussen, O.M.; Glasspool, H. An investigation of governance frameworks for public projects in Norway and the UK. Int. J. Proj. Manag. 2010, 28, 40-50. [CrossRef]

19. Khan, A.; Waris, M.; Ismail, I.; Sajid, M.R.; Ali, Z.; Ullah, M.; Hussain, A. Investigating the Practices of Project Governance in Public Sector Infrastructure Program in Pakistan. Adv. Civ. Eng. 2019, 2019, 1-11. [CrossRef]

20. Ahmed, R.; Mohamad, N.A.b. Performance of project in public sector of pakistan: Developing a framework for future challenges. Serb. Proj. Manag. J. 2014, 4, 3-12. [CrossRef]

21. Khan, A.; Waris, M.; Panigrahi, S.; Sajid, M.R.; Rana, F. Improving the Performance of Public Sector Infrastructure Projects: Role of Project Governance and Stakeholder Management. J. Manag. Eng. 2021, 37, 04020112. [CrossRef]

22. Ahmed, A.; Arshad, M.A.; Mahmood, A.; Akhtar, S. Neglecting human resource development in OBOR, a case of the ChinaPakistan economic corridor (CPEC). J. Chin. Econ. Foreign Trade Stud. 2017, 10, 130-142. [CrossRef]

23. Khan, A.; Waris, M.; Ismail, I.; Sajid, M.R.; Ullah, M.; Usman, F. Deficiencies in Project Governance: An Analysis of Infrastructure Development Program. Adm. Sci. 2019, 9, 9. [CrossRef]

24. Müller, R. Project Governance, Fundamentals of Project Management; Gower Publishing: Aldershot, UK, 2009.

25. Turner, J.R. Governance of project-based management. In Handbook of Project-Based Management; McGraw Hill: New York, NY, USA, 2009; pp. 309-322.

26. Müller, R.; Lecoeuvre, L. Operationalizing governance categories of projects. Int. J. Proj. Manag. 2014, 32, 1346-1357. [CrossRef]

27. McGrath, S.; Whitty, S.J. Redefining governance: From confusion to certainty and clarity. Int. J. Manag. Proj. Bus. 2015, 8, 755-787. [CrossRef]

28. Müller, R.; Pemsel, S.; Shao, J. Organizational enablers for project governance and governmentality in project-based organizations. Int. J. Proj. Manag. 2015, 33, 839-851. [CrossRef]

29. Sanderson, J. Risk, uncertainty and governance in megaprojects: A critical discussion of alternative explanations. Int. J. Proj. Manag. 2012, 30, 432-443. [CrossRef]

30. Clarke, T. Theories of Corporate Governance; Routledge: New York, NY, USA, 2004.

31. Päivärinta, T.; Dertz, W.; Flak, L.S. Issues of Adopting Benefits Management Practices of IT Investments in Municipalities: A Delphi Study in Norway. In Proceedings of the 2007 40th Annual Hawaii International Conference on System Sciences (HICSS’07), Waikoloa, HI, USA, 3-6 January 2007. [CrossRef]

32. Anantatmula, V.S. Project manager leadership role in improving project performnce. Eng. Manag. J. 2010, 22, 13-22. [CrossRef]

33. Islam, Z.; Doshi, J.A.; Mahtab, H.; Ahmad, Z.A. Team learning, top management support and new product development success. Int. J. Manag. Proj. Bus. 2009, 2, 238-260. [CrossRef]

34. Santos-Vijande, M.L.; López-Sánchez, J.Á.; Pascual-Fernández, P. Co-creation with clients of hotel services: The moderating role of top management support. Curr. Issues Tour. 2018, 21, 301-327. [CrossRef]

35. Staehr, L. Understanding the role of managerial agency in achieving business benefits from ERP systems. Inf. Syst. J. 2010, 20, 213-238. [CrossRef]

36. Orlikowski, W.J.; Yates, J.; Okamura, K.; Fujimoto, M. Shaping Electronic Communication: The Metastructuring of Technology in the Context of Use. Organ. Sci. 1995, 6, 423-444. [CrossRef]

37. Crawford, L.H.; Cooke-Davies, T.J. Project governance: The pivotal role of the executive sponsor. In PMI Global Congress North America; PMI: Toronto, ON, Canada, 2005.

38. Too, E.G.; Weaver, P. The management of project management: A conceptual framework for project governance. Int. J. Proj. Manag. 2014, 32, 1382-1394. [CrossRef]

39. Pfeffer, J.; Salancik, G.R. The External Control of Organizations: A Resource Dependence Perspective; Stanford University Press: Stanford, CA, USA, 1978.

40. Andersen, E.S. Value creation using the mission breakdown structure. Int. J. Proj. Manag. 2014, 32, 885-892. [CrossRef]

41. PMI. Delivering Value: Focus on Benefits During Project Execution; Project Management Institute: Newtown Square, PA, USA, 2016.

42. Shenhar, A.J.; Dvir, D. Reinventing Project Management: The Diamond Approach to Successful Growth and Innovation; Harvard Business School Press: Boston, MA, USA, 2007. 
43. Zwikael, O.; Smyrk, J. A General Framework for Gauging the Performance of Initiatives to Enhance Organizational Value. Br. J. Manag. 2012, 23, S6-S22. [CrossRef]

44. Smith, R. Focusing on public value: Something new and something old. Aust. J. Public Adm. 2004, 63, 68-79. [CrossRef]

45. Albert, M.; Balve, P.; Spang, K. Evaluation of project success: A structured literature review. Int. J. Manag. Proj. Bus. 2017, 10, 796-821. [CrossRef]

46. Davis, K. A method to measure success dimensions relating to individual stakeholder groups. Int. J. Proj. Manag. 2016, 34, 480-493. [CrossRef]

47. Davis, K. Different stakeholder groups and their perceptions of project success. Int. J. Proj. Manag. 2014, 32, 189-201. [CrossRef]

48. Koops, L.; van Loenhout, C.; Bosch-Rekveldt, M.; Hertogh, M.; Bakker, H. Different perspectives of public project managers on project success. Eng. Constr. Arch. Manag. 2017, 24, 1294-1318. [CrossRef]

49. Toor, S.-U.; Ogunlana, S.O. Beyond the 'iron triangle': Stakeholder perception of key performance indicators (KPIs) for large-scale public sector development projects. Int. J. Proj. Manag. 2010, 28, 228-236. [CrossRef]

50. Cooke-Davies, T.J. The Real Success Factors in Projects. Int. J. Proj. Manag. 2002, 20, 185-190. [CrossRef]

51. PMI. A Guide to the Project Management Body of Knowledge (PMBOK ${ }^{\circledR}$ Guide), 5nd ed.; Project Management Institute: Newtown Square, PA, USA, 2013.

52. Bowen, P.L.; Cheung, M.-Y.D.; Rohde, F.H. Enhancing IT governance practices: A model and case study of an organization's efforts. Int. J. Account. Inf. Syst. 2007, 8, 191-221. [CrossRef]

53. Crawford, L.; Cooke-Davies, T.; Hobbs, B.; Labuschagne, L.; Remington, K.; Chen, P. Governance and support in the sponsoring of projects and programs supplement. Proj. Manag. J. 2008, 39, S43-S55. [CrossRef]

54. Guo, F.; Chang-Richards, Y.; Wilkinson, S.; Li, T.C. Effects of project governance structures on the management of risks in major infrastructure projects: A comparative analysis. Int. J. Proj. Manag. 2014, 32, 815-826. [CrossRef]

55. Joslin, R.; Müller, R. The relationship between project governance and project success. Int. J. Proj. Manag. 2016, 34, 613-626. [CrossRef]

56. Abednego, M.P.; Ogunlana, S.O. Good project governance for proper risk allocation in public-private partnerships in Indonesia Int. J. Proj. Manag. 2006, 24, 622-634. [CrossRef]

57. Flyvbjerg, B.; Bruzelius, N.; Rothengatter, W. Megaprojects and Risk: An Anatomy of Ambition; Cambridge University Press: Cambridge, UK, 2003.

58. Marrewijk, A.V.; Clegg, S.R.; Pitsis, T.S.; Veenswijk, M. Managing public-private megaprojects: Paradoxes, complexity, and project design. Int. J. Proj. Manag. 2008, 26, 591-600. [CrossRef]

59. Lu, J.W.; Liang, X.; Shan, M.; Liang, X. Internationalization and Performance of Chinese Family Firms: The Moderating Role of Corporate Governance. Manag. Organ. Rev. 2015, 11, 645-678. [CrossRef]

60. Ali, M.; Li, Z.; Khan, S.; Shah, S.J.; Ullah, R. Linking humble leadership and project success: The moderating role of top management support with mediation of team-building. Int. J. Manag. Proj. Bus. 2020, 14, 1753-8378. [CrossRef]

61. Zwikael, O. Top management involvement in project management: A cross country study of the software industry. Int. J. Manag. Proj. Bus. 2008, 1, 498-511. [CrossRef]

62. Young, R.; Poon, S. TMS-Almost always necessary and sometimes sufficient for success: Findings from a fuzzy set analysis. Int J. Proj. Manag. 2013, 31, 943-957. [CrossRef]

63. Bruque-Cámara, S.; Vargas-Sánchez, A.; Hernández-Ortiz, M.J. Organizational determinants of IT adoption in the pharmaceutical distribution sector. Eur. J. Inf. Syst. 2004, 13, 133-146. [CrossRef]

64. Jugdev, K.; Muller, R. A Retrorospective Look at our Evolving Understanding of Project Success. Proj. Manag. J. 2005, 36, 19-31. [CrossRef]

65. O'Brochta, M. Great project managers. In PMI Global Congress Proceedings; PMI: Sao Paulo, Brazil, 2008.

66. Boonstra, A. How do top managers support strategic information system projects and why do they sometimes withhold this support? Int. J. Proj. Manag. 2013, 31, 498-512. [CrossRef]

67. Young, R.; Jordan, E. Top management support: Mantra or necessity? Int. J. Proj. Manag. 2008, 26, 713-725. [CrossRef]

68. Ali, U.; Kidd, C. Barriers to effective configuration management application in a project context: An empirical investigation. Int. J. Proj. Manag. 2014, 32, 508-518. [CrossRef]

69. Mir, F.A.; Pinnington, A. Exploring the value of project management: Linking Project Management Performance and Project Success. Int. J. Proj. Manag. 2014, 32, 202-217. [CrossRef]

70. Ayat, M.; Imran, M.; Ullah, A.; Kang, C.W. Current trends analysis and prioritization of success factors: A systematic literature review of ICT projects. Int. J. Manag. Proj. Bus. 2020, 14, 652-679. [CrossRef]

71. Pacagnella, A.C., Jr.; da Silva, S.L.; Pacífico, O.; de Arruda Ignacio, P.S.; da Silva, A.L. Critical Success Factors for Project Manufacturing Environments. Proj. Manag. J. 2019, 50, 243-258. [CrossRef]

72. Thompson, J.D. Organizations in Action: Social Science Bases of Administrative Theory; McGraw-Hill: New York, NY, USA, 2011.

73. Oliver, C. Strategic responses to institutional processes. Acad. Manag. Rev. 1991, 16, 145-179. [CrossRef]

74. Hillman, A.J.; Dalziel, T. Boards of directors and firm performance: Integrating agency and resource dependence perspectives. Acad. Manag. Rev. 2003, 28, 383-396. [CrossRef]

75. Madanayake, O.; Gibson, P. Taking the mystery out of the concept of top management support: The context of information technology projects. In Cambridge Business \& Economics Conference; University of Cambridge: Cambridge, UK, 2014. 
76. Biedenbach, T.; Müller, R. Paradigms in project management research: Examples from 15 years of IRNOP conferences. Int. J. Manag. Proj. Bus. 2011, 4, 82-104. [CrossRef]

77. Teddlie, C.; Tashakkori, A. Foundations of Mixed Methods Research: Integrating Quantitative and Qualitative Approaches in the Social and Behavioral Sciences; Sage Publications Inc.: Thousand Oaks, CA, USA, 2009.

78. Podsakoff, P.M.; MacKenzie, S.B.; Podsakoff, N.P. Sources of Method Bias in Social Science Research and Recommendations on How to Control It. Annu. Rev. Psychol. 2012, 63, 539-569. [CrossRef]

79. Pesämaa, O.; Zwikael, O.; Hair, J.F.; Huemann, M. Publishing quantitative papers with rigor and transparency. Int. J. Proj. Manag. 2021, 39, 217-222. [CrossRef]

80. Eichhorn, B.R. Common Method Variance Techniques; Cleveland State University: Cleveland, OH, USA, 2014.

81. Aga, D.; Noorderhaven, N.; Vallejo, B. Transformational leadership and project success: The mediating role of team-building. Int. J. Proj. Manag. 2016, 34, 806-818. [CrossRef]

82. Müller, R.; Turner, J.R.; Andersen, E.S.; Shao, J.; Kvalnes, Ø. Governance and Ethics in Temporary Organizations: The Mediating Role of Corporate Governance. Proj. Manag. J. 2016, 47, 7-23. [CrossRef]

83. Haq, S.U.; Liang, C.; Gu, D.; Du, J.T.; Zhao, S. Project Governance, Project Performance, and the Mediating Role of Project Quality and Project Management Risk: An Agency Theory Perspective. Eng. Manag. J. 2018, 30, 274-292. [CrossRef]

84. Scott-Young, C.; Samson, D. Project success and project team management: Evidence from capital projects in the process industries. J. Oper. Manag. 2007, 26, 749-766. [CrossRef]

85. Bryde, D. Perceptions of the impact of project sponsorship practices on project success. Int. J. Proj. Manag. 2008, 26, 800-809. [CrossRef]

86. Khang, D.B.; Moe, T.L. Success Criteria and Factors for International Development Projects: A Life-Cycle-Based Framework. Proj. Manag. J. 2008, 39, 72-84. [CrossRef]

87. Suprapto, M.; Bakker, H.L.; Mooi, H.G. Relational factors in owner-contractor collaboration: The mediating role of teamworking. Int. J. Proj. Manag. 2015, 33, 1347-1363. [CrossRef]

88. Churchill, G.A., Jr. A Paradigm for Developing Better Measures of Marketing Constructs. J. Mark. Res. 1979, 16, 64-73. [CrossRef]

89. Anderson, J.C.; Gerbing, D.W. Structural equation modeling in practice: A review and recommended two-step approach. Psychol. Bull. 1988, 103, 411-423. [CrossRef]

90. Hair, J.F.; Black, W.C.; Babin, B.J. Multivariate Data Analysis: A Global Perspective, 7th ed.; Pearson Education: Upper Saddle River NJ, USA, 2010.

91. Fornell, C.; Larcker, D.F. Structural equation models with unobservable variables and measurement error: Algebra and statistics J. Mark. Res. 1981, 18, 328-388. [CrossRef]

92. Bagozzi, R.P.; Yi, Y. On the evaluation of structural equation models. J. Acad. Mark. Sci. 1988, 16, 74-94. [CrossRef]

93. Sharma, S.; Richard, M.D.; Gur-Arie, D. Identification and analysis of moderator variables. J. Mark. Res. 1981, 18, 291-300. [CrossRef]

94. Sharma, N. The role of pure and quasi-moderators in services: An empirical investigation of ongoing customer-service-provider relationships. J. Retail. Consum. Serv. 2003, 10, 253-262. [CrossRef]

95. Joslin, R.; Müller, R. Relationships between a project management methodology and project success in different project governance contexts. Int. J. Proj. Manag. 2015, 33, 1377-1392. [CrossRef]

96. Müller, R.; Martinsuo, M. The impact of relational norms on information technology project success and its moderation through project governance. Int. J. Manag. Proj. Bus. 2015, 8, 154-176. [CrossRef]

97. Ahmed, R.; Bin Mohamad, N.A.; Ahmad, M.S. Effect of multidimensional top management support on project success: An empirical investigation. Qual. Quant. 2016, 50, 151-176. [CrossRef]

98. Hermano, V.; Martín-Cruz, N. The role of top management involvement in firms performing projects: A dynamic capabilities approach. J. Bus. Res. 2016, 69, 3447-3458. [CrossRef]

99. Fareed, M.Z.; Su, Q.; Awan, A.A. The effect of emotional intelligence, intellectual intelligence and transformational leadership on project success; an empirical study of public projects of Pakistan. Proj. Leadersh. Soc. 2021, 2, 100036. [CrossRef]

100. Biesenthal, C.; Wilden, R. Multi-level project governance: Trends and opportunities. Int. J. Proj. Manag. 2014, 32, 1291-1308. [CrossRef]

101. Lappi, T.; Aaltonen, K. Project governance in public sector agile software projects. Int. J. Manag. Proj. Bus. 2017, 10, 263-294. [CrossRef]

102. Elkington, J. Cannibals with Forks: The Triple Bottom Line of 21st Century Business; Capstone Publishing Ltc.: Oxford, UK, 1997.

103. Musawir, A.U.; Serra, C.E.M.; Zwikael, O.; Ali, I. Project governance, benefit management, and project success: Towards a framework for supporting organizationalstrategy implementation. Int. J. Proj. Manag. 2017, 35, 1658-1672. [CrossRef]

104. Fareed, M.Z.; Su, Q. Transformational Leadership and Project Success: A Mediating Role of Public Service Motivation. Adm. Soc. 2021, 00953997211040466. [CrossRef] 